\title{
Review and prospect of corporate social responsibility research
}

\author{
Jinfang $\mathrm{Li}^{*}$ \\ Department of Economics and Management, Nanjing University of Science and Technology, \\ Nanjing, China \\ ${ }^{*}$ Corresponding author: li_jin_fang@126.com
}

\begin{abstract}
In this paper, through the review of corporate social responsibility related research, the concept of corporate social responsibility, impact factors, impact results, action mechanism and other aspects of the integrated analysis. The results show that there is no unified definition of corporate social responsibility at present, but they all emphasize a point of view, that is, enterprises must consider the impact on stakeholders in various business activities. In addition, according to our analysis, we find that most research on corporate social responsibility (CSR) is conducted at the corporate level, but there is a growing interest in the analysis of individual level, especially employee level. However, the existing literature shows that the impact of CSR on potential employees has not been fully studied. In addition, when discussing the impact of corporate social responsibility on enterprises, few studies consider the impact of context. From these findings, we determine the direction of future research.
\end{abstract}

Keywords: Corporate Social Responsibility, Review, Integration Model.

\section{Introduction}

Corporate social responsibility has been widely concerned by academia and industry, and some people even regard it as an effective strategy to gain competitive advantage ${ }^{[1]}$. Studies show that it is very important to engage in specific CSR activities, and a company will lose the support of some important stakeholder groups if it lacks CSR ${ }^{[1]}$. However, existing studies show that although the academic circle has carried out extensive studies on the connotation, measurement, antecedent variables, situational factors and outcome variables of corporate social responsibility. However, the existing researches mainly discuss theory from different perspectives, such as its background, disciplinary origin, process model, value realization mechanism and interpretation of key elements. Few researches systematically sort out the existing research results, development context and main theoretical perspectives in this field. Based on the above deficiencies, this paper has carried out an integrated analysis of the concept connotation, theoretical basis, measurement, antecedent variables, situational factors and results and effects of corporate social responsibility, sorted out the development of corporate social responsibility research veins, and then put forward an integrated research framework of corporate social responsibility research status. In order to provide reference and inspiration for the theoretical research and practical development of corporate social responsibility.

\section{Concepts of corporate social responsibility}

\subsection{Definition of corporate social responsibility}

\subsubsection{Foreign definitions of corporate social responsibility}

Corporate social responsibility can be broadly defined as a company's status and activities and its perceived social obligations and interests of major stakeholders ${ }^{[3]}$.CSR refers to "context-specific organizational actions and policies that take into account stakeholder expectations and the triple bottom line of economic, social and environmental performance. ${ }^{[4]}$ Siegel et al. defined CSR as "the company engaged in commercial activities to promote social welfare, which exceeded the company's own interests and the needs of the law" [5]. This concept includes three elements :(1) positive social 
output-promoting social welfare (2) market-oriented and (3) socially oriented voluntary behavior. Mackey et al. Further developed this definition into "voluntary corporate action aimed at improving social situation" ${ }^{[6]}$. The definition of these concepts is broad and lacks specific content and scope limits, which may be caused by the wide range of CSR activities. For example, CSR activities include integrating prosocial features into products or production processes (such as products being environmentally friendly or production processes using environmentally friendly technologies to reduce pollutant emissions), respecting employees and protecting their interests in human resource management practices. In the research on the concept and connotation of corporate social responsibility, the definition proposed by Carroll (1979) is most accepted by scholars. He believes that corporate social responsibility is a three-dimensional pyramid model with four aspects, each dimension overlapping to form corporate social responsibility. These three dimensions are respectively the social association's expectation of the responsibility of the enterprise organization in the four aspects of economy, law, ethics and voluntary in a certain period of time. Voluntary responsibility mainly refers to the voluntary responsibility of the enterprise for the public welfare and charity. Wang and Juslin combined CSR with ancient Chinese Confucianism and defined it as the harmonious operation of an enterprise and its treatment of the whole society in a harmonious way, including environmental protection and caring for the society ${ }^{[7]}$. Corporate social responsibility is defined as the actions and policies taken by an organization in response to specific situations that aim to improve the well-being of stakeholders by taking into account the triple bottom line of economic, social and environmental performance ${ }^{[8]}$.

\subsubsection{Domestic definition of corporate social responsibility}

Daifu Lu believes that while obtaining the maximum benefits for shareholders, enterprises should assume the responsibility of safeguarding social interests, and should safeguard the rights and interests of stakeholders other than shareholders. This is a beneficial supplement to the idea of "shareholder interest centralization". Since then, Daifu Lu has carried out a more in-depth study on corporate social responsibility, and believes that enterprises should have two aspects of the ability at the same time: first, strong profitability, which can make investors profit, is the basic ability required by enterprises to fulfill social responsibility. The second is the ability to safeguard the rights and interests of all corporate stakeholders. In addition, he also proposed a triangle model of economy, law and society supporting each other similar to Carroll's pyramid model. Qian Luo believes that, in a broad sense, corporate social responsibility refers to all the responsibilities an enterprise undertakes for the whole society, including economic, legal and moral responsibilities. In a narrow sense, corporate social responsibility refers to the responsibility of an enterprise to shareholders, employees, consumers, suppliers and other stakeholders, including profits ${ }^{[9]}$. Some scholars believe that "corporate social responsibility is a comprehensive responsibility, including economic responsibility, legal responsibility and moral responsibility, which enterprises are obliged to undertake with stakeholders as the target". Wenhong Sun et al. pointed out that corporate social responsibility is divided into two types, one is basic social responsibility, the other is other social responsibility ${ }^{[10]}$. Basic social responsibility is mainly defined by laws and regulations or administrative instructions. It is usually the mandatory requirements of the state on enterprises, including social responsibility for internal employees, consumers and ecological environment. Other social responsibilities are mainly the responsibilities of enterprises in social welfare activities, charity construction and other aspects. Such responsibilities are usually non-rigid and depend on enterprises' own sense of social responsibility and moral consciousness.

Although there is no accepted academic definition of corporate social responsibility, the academic community has formed a consensus that CSR refers to the responsibility of enterprises for labor relations, customers, the ecological environment and the society and other stakeholders while making profits. In other words, in various business activities, enterprises must consider the impact on stakeholders, including economic, social and environmental impacts. Table 1 summarizes some scholars' studies on the concept of CSR. 
Table 1. Concepts of corporate social responsibility

\begin{tabular}{|c|c|c|}
\hline Years & Author & Views \\
\hline 1979 & Carroll & $\begin{array}{c}\text { A three-dimensional pyramid model, three dimension has four aspects, } \\
\text { each dimension layer upon layer atop the other Constitute the corporate } \\
\text { social responsibility, the three dimensions are respectively society in a } \\
\text { certain period to the enterprise organization in the economic, legal, ethical, } \\
\text { and voluntary four aspects, such as the responsibility of the expectations, } \\
\text { the voluntary liability mainly refers to the enterprises in the voluntary } \\
\text { responsibility for public welfare charity }\end{array}$ \\
\hline 1997 & $\begin{array}{l}\text { Brown \& } \\
\text { Dacin }\end{array}$ & $\begin{array}{r}\text { The status and activities of the company and its } \\
\text { and interests of key stakel }\end{array}$ \\
\hline 2001 & Siegel & $\begin{array}{l}\text { Companies engage in business activities th } \\
\text { beyond their own interests and beyond the }\end{array}$ \\
\hline 2009 & $\begin{array}{l}\text { Wang \& } \\
\text { Juslin }\end{array}$ & $\begin{array}{l}\text { Enterprises operate in harmony and treat the whole society in a } \\
\text { harmonious way, including protecting the environment and caring for the } \\
\text { society }\end{array}$ \\
\hline 2010 & Gond & $\begin{array}{l}\text { Including business actions that go beyond their economic, technical and } \\
\text { legal requirements }\end{array}$ \\
\hline 2010 & Lai & $\begin{array}{r}\text { Free allocation of corporate resources for the be } \\
\text { as a means of strengthening linkages }\end{array}$ \\
\hline 2016 & $\begin{array}{l}\text { Tsai Y H, Lin } \\
\text { C P, Hsu Y C, } \\
\text { et al }\end{array}$ & $\begin{array}{r}\text { Contextualized organizational actions and polic } \\
\text { the triple bottom line of stakeholder expectations } \\
\text { environmental performan }\end{array}$ \\
\hline 2018 & $\begin{array}{l}\text { Akremi\& } \\
\text { Swaen }\end{array}$ & $\begin{array}{c}\text { Organization-specific actions and policies aimed at improving the well- } \\
\text { being of stakeholders by taking into account the triple bottom line of } \\
\text { economic, social and environmental performance }\end{array}$ \\
\hline 2002 & Daifu Lu & $\begin{array}{l}\text { While obtaining the maximum benefits for shareholders, the enterprise } \\
\text { undertakes the responsibility of safeguarding social interests. The } \\
\text { enterprise should safeguard the rights and interests of stakeholders other } \\
\text { than shareholders }\end{array}$ \\
\hline 2011 & Qian Luo & $\begin{array}{l}\text { In a broad sense, corporate social responsibility refers to all the } \\
\text { responsibilities that an enterprise undertakes for the whole society, } \\
\text { including economic, legal and moral responsibilities. In a narrow sense, } \\
\text { corporate social responsibility refers to the responsibility of an enterprise } \\
\text { to shareholders, employees, consumers, suppliers and other stakeholders, } \\
\text { including profits }\end{array}$ \\
\hline 2016 & Hongwen Sun & $\begin{array}{l}\text { Corporate social responsibility is divided into basic social responsibility } \\
\text { and other social responsibility. Basic social responsibility mainly refers to } \\
\text { the responsibilities explicitly stipulated by laws and regulations or } \\
\text { administrative instructions. Generally speaking, it is some mandatory } \\
\text { requirements put forward by the state on enterprises, including social } \\
\text { responsibility for internal employees, consumers and ecological } \\
\text { environment. Other social responsibilities are mainly the responsibilities of } \\
\text { enterprises in social welfare activities and charity construction }\end{array}$ \\
\hline
\end{tabular}

\subsection{Dimensions and measurements of corporate social responsibility}

There are also various ways to divide the dimensions of corporate social responsibility, which can be divided from three different perspectives, namely, hierarchical perspective, stakeholder perspective and hybrid perspective. 


\subsubsection{A perspective of hierarchical}

The dimensions of corporate social responsibility based on hierarchical perspective mainly include "three concentric circles" model, "triangle" model and "pyramid" model. The "three concentric circles" model was proposed by CED (Economic Development Committee) in 1979, which divides CSR into three parts. The innermost layer represents the basic economic responsibility of the enterprise, the middle layer represents that the enterprise should protect the rights and interests of consumers, protect the environment and maintain a good employee relationship, and the outermost layer represents the ambiguous social responsibility. The "pyramid" model of corporate social responsibility proposed by Carroll (1999) is widely cited at present. This model includes corporate economic responsibility, corporate legal responsibility, moral responsibility and charitable responsibility from top to bottom. These four levels are interconnected and constitute corporate social responsibility ${ }^{[29]}$. Ferrell is an early scholar who studied corporate social responsibility scales. He and his colleagues developed a set of four dimensions of CSR scale, including four dimensions of economy, law, ethics and free will ${ }^{[1]}$.

\subsubsection{A perspective of stakeholders}

Freeman first proposed the CSR theory as the stakeholder theory in 1984. According to the stakeholder theory, enterprises should not only consider the interests of owners, but also the interests of other stakeholders, including shareholders, employees, suppliers and consumers, in production and operation. On the basis of previous studies and stakeholder theory, Turker developed a 42-item corporate social responsibility scale. Including social/non-social corporate social responsibility (CSRS), corporate social responsibility to employees (CSRE), corporate social responsibility to customers (CSRC) and corporate social responsibility to the government (CSRG) and other four dimensions $^{[12]}$. Xianfu He conducted in-depth research on the scale of corporate social responsibility during his doctoral study. He selected 22 items suitable for The research situation in China based on the scale of 42 items developed by Ferrell. It is divided into five dimensions: responsibility for employees, responsibility for products, responsibility for integrity and justice, responsibility for charity and public welfare, and responsibility for the environment ${ }^{[13]}$. From the perspective of related interests, Tian Hong et al. also divided corporate social responsibility of online media into the same five dimensions, but with different levels.

\subsubsection{A mixed perspective}

The synthetic dimension of the mixed perspective is mainly the synthesis and adjustment of the pyramid model and related stakeholder dimension, which is a method adopted by many scholars at present. Dahlsrud evaluated the practice of corporate social responsibility from five dimensions: environmental responsibility, economic responsibility, social responsibility, shareholder responsibility and voluntary charitable responsibility ${ }^{[15]}$; Sarkar et al. proposed that corporate social responsibility should include shareholder interest responsibility, economic responsibility, sustainable development responsibility, voluntary public welfare and charity responsibility, moral responsibility and social responsibility based on the research of scholars in recent years ${ }^{[16]}$. Bing Hu believes that listed tourism companies should not only be responsible for shareholders and the government, but also take economic, political and legal responsibilities, as well as employees, partners, customers, the environment and communities ${ }^{[16]}$. Shangkun $\mathrm{Xu}$ argues that China's enterprises in addition to economic responsibility and legal liability, also should promote social (social responsibility), to protect the environment (environmental responsibility), promoting employment (job), ensure social harmony and stability, social stability, progress, responsibility), respect for human rights (humanistic responsibility), and the lawful rights and interests safeguard customers (clients) ${ }^{[18]}$

In addition, division from the perspective of a certain stakeholder is also a popular perspective in recent years, because the theoretical model of stakeholder and the mixed perspective model, although comprehensive in content, are also inaccurate. In real life, it is difficult for people to understand the responsibility of an enterprise for each stakeholder, which increases the difficulty of actual research. Enterprises need financial support to undertake social responsibility and carry out activities. As an important stakeholder of enterprises, consumers are an important economic source of enterprises. 
Therefore, scholars have launched a heated discussion on CSR from the perspective of consumers. Liyin Jin studied CSR from the perspective of consumers in China, mainly referring to the relevant theoretical results of foreign scholars, and concluded that CSR from the perspective of consumers includes five dimensions: charitable responsibility, public welfare responsibility, consumer responsibility, economic responsibility and environmental responsibility ${ }^{[19]}$, has been widely used by domestic scholars. Hui Tang believes that corporate social responsibility of hotels from the perspective of consumers includes five aspects: charity, community public welfare, environment, consumers and employees $^{[20]}$. Xiaojun $\mathrm{Xu}$ divides the consumer perspective of corporate social responsibility into three dimensions: consumer, environment and community ${ }^{[21]}$. Thus, scholars have not formed a unified division of CSR dimensions from the perspective of consumers.

\section{Theoretical foundations}

\subsection{Signal theory}

Signal theory is used to explain how to reduce information asymmetry between two parties (either individual level or organizational level) when they have different information channels through signal transmission. Specifically, one is the sender of the signal, choosing whether and how to communicate the information. The other party, the receiver of the signal, chooses how to interpret the signal. Signal theory is essentially concerned with reducing information asymmetry between two parties: the sender and the receiver of a signal ${ }^{[22]}$.For example, Spence applied signal theory to the labor market to explain the signaling function of education ${ }^{[23]} \mathrm{He}$ believes that because employers lack complete information about candidates, candidates use their higher education to signal their quality and distinguish themselves from low-quality candidates (who are unable to show their higher education), thus reducing information asymmetry. Corporate social responsibility represents a signal that a company cares about the well-being of stakeholders and the society as a whole, and is willing to take care of others.

\subsection{Social identity theory}

In the 1980s, social scientists represented by Tajefl began to focus their research on groups and self-concept, initiating subsequent research topics such as "social classification" and "self-definition". Among them, the most representative is the theory of social identity. The social identity theory holds that individuals can generate social identity to their own groups and generate in-group preference and out-group bias through social classification and social comparison. According to Tajefl, social identification is "an individual's recognition that he or she belongs to a particular social group, while also recognizing the emotional and value meaning that being a member of that group brings to him." ${ }^{[24]}$ Social Categorization and Social Comparison are two important aspects of Social identity ${ }^{[25]}$ First, in order to quickly understand and respond to the outside world, people subconsciously categorize external people, things, and things according to certain characteristics. On the basis of this classification, people can perceive the differences between groups and extract the archetypal characteristics of different groups. When people categorize socially they include themselves in a category. Once the archetypal characteristics of a group are highlighted, individuals will compare the archetypal characteristics of the group with their own characteristics, and then classify themselves into a certain group based on the comparison results, thus generating a perception of identity that individuals belong to a certain group. This process is self-categorization in the process of social classification ${ }^{[26]}$.Furthermore, individuals will make social comparisons after self-categorizing. Through comparison between groups, individuals develop a sense of "we are superior to them", which leads to social identification with their group. Social classification and social comparison make individuals derive their identity recognition of belonging to a certain group from their self-concept, which is called social identity $27^{[}$.After social identification with a specific group, individuals tend to associate positive and positive characteristics with the group they belong to, thus forming in-group preference. Thus, social identity may cause an individual to conform, advocate and support the group with which he identifies ${ }^{[27]}$.It should be emphasized that social identity theory believes that the basic 
motivation for individuals to identify with groups is to achieve self-promotion and improve selfesteem $^{[7]}$. By classifying the self into a superior group and choosing to associate with the positive characteristics of the group, an individual's self-esteem can be improved and a positive self-evaluation can be generated ${ }^{[26]}$. Social classification and social comparison are important factors to promote individuals' social identification with specific groups. This study chooses social identity theory as the theoretical framework of the thesis mainly based on two aspects .

First of all, the phenomenon explained by social identity theory is consistent with the research question of this paper. Social identity theory mainly explores why individuals identify with and prefer specific groups ${ }^{[28]}$, the focus of this paper is "why job seekers prefer companies with good CSR performance". The logical consistency of the research problem indicates that it is appropriate to use social identity theory to explain the topic concerned in this paper. Secondly, corporate social responsibility can enhance job seekers' recognition of the company. According to social identity theory, the basic motivation for individuals to identify with groups is to achieve self-promotion and improve self-esteem ${ }^{[26]}$.Therefore, for this motivation, job seekers tend to classify themselves as enterprises with good social responsibility performance, and have a high degree of identification with such enterprises. Corporate social responsibility plays an important role in the process of social identity of job seekers to the recruitment enterprise, which also shows the rationality of using social identity theory in this study.

\subsection{Person-organization fit}

Person-organization fit generally refers to the compatibility between an individual and an organization, which is reflected in the similarity and complementarity between the two. Many studies have shown that different individuals are attracted to different jobs or organizations in different ways, due to their own differences in interests, preferences, personality and so on. In addition, when the organization is more consistent with the goals and values of job seekers, individuals will be more attracted by the organization. Personal-organizational fit is one of the most popular matches in personal-environment fit models. Person-organization fit refers to the matching degree between the needs, goals and values of an organization and the norms, values and compensation system of the organization. It emphasizes the compatibility between individual characteristics and those of the entire organization. Existing studies often focus on the fit of individual characteristics and organizational culture, individual values and organizational values, as well as their matching in goals.

\section{Research status of corporate social responsibility}

Corporate social responsibility researches are mainly carried out at two levels, namely, organizational level (macro level) and individual level (micro level). Through literature review, it is found that most studies on CSR are focused on the macro level, but few are carried out at the micro level ${ }^{[29]}$.This article will review the influencing factors and influencing results in the CSR research field. Each aspect is distinguished from the organizational level and the individual level.

\subsection{Antecedents of corporate social responsibility researches}

\subsubsection{Antecedents at the organizational level}

At the organizational level, some important predictors of corporate CSR investment include utilitarian motivation, normative motivation, moral responsibility and institutional pressure of the company ${ }^{[29]}$.Utilitarian motivation refers to the company's belief that CSR will bring benefits to the company and thus engage in CSR, such as increased competitiveness and increased legitimacy. Normative motivation means that companies are driven to engage in CSR by normative reasons, such as perceived responsibilities and obligations. Moral responsibility refers to the company's choice of CSR input due to a higher level of command or moral and responsibility. In addition, the antecedent variable of corporate CSR also comes from institutional pressure. The implementation of CSR by competitors or many enterprises in the industry leads to the general expectation of stakeholders on 
corporate CSR. In China, it is found that the charitable donation activities of enterprises in the region will form the regional moral legal standard and regional isomorphic institutional pressure, thus driving the corporate charitable donation behavior ${ }^{[30]}$. Other predictive factors such as the political connection of corporate managers affect corporate charitable donations, and product market competition affects corporate charitable donations ${ }^{[29]}$. Special variables related to the organizational level also have an impact on CSR activities and predict the company's tendency to engage in CSR. These variables include the company's mission and values, long-term institutional ownership and senior management ownership, and the company's governance structure ${ }^{[29]}$. Foreign-funded enterprises have significantly improved the social responsibility performance of Chinese enterprises through supply chain pressure $^{[31]}$.

\subsubsection{Antecedents at the individual level}

At the individual level, Jianan $\mathrm{Li}$ and others reviewed the factors that affect corporate social responsibility investment and found that the factors that affect individual investment in CSR activities include: individual values, the degree of consistency between individual values and organizational values, employees' psychological needs, and employees' expectations psychology and individual concern about special issues ${ }^{[31]}$. Individual values are part of the decision-making process and are important to understand how values affect individual CSR engagement. In addition, the latest research shows that social trust has a significant positive impact on corporate social responsibility ${ }^{[32]}$.

\subsection{Consequences of corporate social responsibility researches}

\subsubsection{Consequences at the organizational level}

Scholars have conducted a wide range of discussions on the impact of corporate social responsibility, but most of the studies are focused on the institutional or organizational level. Weber believes that the benefits of corporate social responsibility are as follows ${ }^{[33]}$ : improve corporate image, reputation and brand equity, recruitment ability, reducing costs and risks and increase income. In addition, CSR can add value to a business by meeting expectations of good corporate behaviour, opening up new growth opportunities, improving access to capital, innovation and customer/employee engagement ${ }^{[34]}$. Brammer et al. proposed that CSR can help enterprises gain a good reputation ${ }^{[35]}$. In addition, a large number of literatures have explored the impact of corporate social responsibility on corporate performance ${ }^{[36,37]}$. Studies show that corporate social responsibility will have an important impact on employee turnover rate and improvement of employee relationship ${ }^{[31]}$. Tkalac's empirical research shows that corporate social responsibility has a significant positive impact on corporate image, corporate reputation and corporate transparency ${ }^{[38]}$. Customer perception of CSR can enhance positive brand association and brand awareness, both of which are considered components of an employer's brand equity. Further studies by Wang et al. found that CSR can increase employer brand equity ${ }^{[39]}$.

\subsubsection{Consequences at the individual level}

In recent years, with the continuous attention of the academic circle to the research of corporate social responsibility, some scholars began to discuss the impact of corporate social responsibility at the individual level. For example, Mueller et al. found that corporate social responsibility can positively affect employees' emotional commitments ${ }^{[40]}$; Choi et al's research found that corporate social responsibility can positively affect employees' organizational citizenship behavior through employee job satisfaction ${ }^{[41]}$. Research by Aguinis et al. has shown that corporate social responsibility has a significant impact on organizational commitment, organizational citizenship behavior, willingness to leave, job performance, and low employee turnover. Weber found that corporate social responsibility can improve employee motivation and loyalty ${ }^{[33]}$. In the research at the individual level, some studies have begun to focus on the impact of corporate social responsibility on the external stakeholders of the organization. Existing research suggests that communicating CSR information to job seekers can help companies become more attractive to job seekers ${ }^{[43]}$. For example, Turban et al. put forward that CSR can improve the attractiveness of recruitment enterprises through the mechanism of social identity [44], believing that job seekers will expect to gain an improvement in self-concept 
from working for enterprises with good CSR performance, and thus prefer enterprises with good CSR performance. By asking participants to rate the attractiveness of 189 real companies based on their CSR information, the study showed that CSR did indeed make recruiters more attractive to job seekers. Bauer et al. found that if the company's care for the environment is reflected in the recruitment brochure, it will have a good effect on attracting potential job applicants ${ }^{[45]}$. Similarly, Behrend et al.'s research results show that companies publishing information about environmental protection on the company's official website can increase job seekers' willingness to apply for a job ${ }^{[46]}$. Research has found that employee-oriented social responsibility has a greater impact on organizational attractiveness than other dimensions of social responsibility ${ }^{[47]}$. In addition, CSR related outcome variables include consumer loyalty, consumer resistance, consumer purchase intention, employee engagement, in-role performance, and employee creative engagement ${ }^{[31]}$. From the perspective of the brand, Shuai Zhong studied the relationship between CSR and brand emotion. The results showed that CSR has a positive effect on the two dimensions of brand's true affection and due affection ${ }^{[1]}$. Tian Min studied the impact of product-related responsibility behaviors, charitable behaviors, and public welfare practices on consumer brand evaluation of the three CSR behaviors ${ }^{[48]}$. The research found that product-related responsibility behaviors and charitable behaviors in CSR behavior have a significant effect on consumer brand evaluation. Among them, product-related responsibility behaviors have the most significant impact. In addition, in corporate charity behaviors, the matching of products and CSR behaviors has a moderating effect on consumer brand evaluation. Scholars investigated employees of 12 enterprises in Hunan province and Guangdong Province ${ }^{[49]}$, and confirmed that internal and external social responsibility had a positive impact on employees' sense of work meaning, and perceived organizational support played a partial intermediary role between internal corporate social responsibility and employees' sense of work meaning. Organizational pride plays a completely mediating role between external CSR and employees' sense of job meaning. Corporate social responsibility behavior has a positive and significant impact on employees' internal work motivation and psychological capital, and psychological capital plays an intermediary role between corporate social responsibility and employees' internal work motivation ${ }^{[50]}$. The fulfillment of social responsibilities at the initial stage of an enterprise can improve employee satisfaction, and fulfilling social responsibilities at the advanced stage can not only enhance employee satisfaction, but also significantly promote employee centripetal and loyalty ${ }^{[51]}$. Aimin Yan discussed the influence mechanism of employees' perception of CSR on employee voice behavior in the context of Chinese culture $^{[52]}$.

\subsection{The intermediary mechanism and boundary conditions of CSR researches}

Research shows that the mediating variables of CSR and results are organizational identity and organizational pride ${ }^{[53]}$. By studying the relationship between CSR and organizational attractiveness, Jones found that expected pride, perceived value matching and expected treatment mediated the relationship between CSR and organizational attractiveness. Pfister et al. found that perceived organizational support, company image, and individual-organization matching have an intermediary effect on the relationship between CSR and organizational attractiveness, while personal characteristics, demographic data, and individual corporate social responsibility positions have a moderating effect. In recent years, studies have also explored the intermediary mechanism and boundary conditions of the impact of corporate social responsibility on job seekers ${ }^{[54]}$. Research such as Greening et al. found that the gender of job applicants will regulate the impact of corporate social responsibility on job applicants ${ }^{[55]}$. Research by Luce et al. showed that job applicants' familiarity with the company plays an intermediary role between corporate social responsibility and the company's attractiveness to job applicants ${ }^{[56]}$. In this field, Jones et al., based on the perspective of signal theory, believe that corporate social responsibility can affect the attractiveness of companies to job applicants through three signals: organizational reputation, perceived value matching, and expected treatment ${ }^{[53]}$. Lin Zhang et al. found that the size of a company affects the relationship between a person's perception of CSR and his sense of pride, thereby affecting the attractiveness of 
the organization ${ }^{[57]}$. Corporate responsibility influences the purchase intention of consumers, job seekers and investment intentions of investors through influencing identity attraction and organizational trust, and corporate social responsibility information sources play a moderating role in this process ${ }^{[29]}$. Recent studies show that in tourism enterprises, socially responsible human resource management practices can promote the emergence of employees' pro-environment behaviors, employees' environmental commitment plays a mediating role in this effect, and environmental transformational leadership and employees' green self-efficacy play a moderating role in the above relationship ${ }^{[32]}$. In addition, studies have shown that external formal institutions (market-oriented environment) have a positive moderating effect between social trust and corporate social responsibility.

\section{Conclusions and future research directions}

While academics also see CSR as a strength, they also point out that while potential applicants believe that corporate social responsibility affects their perception of organizations, the actual impact of CSR on recruitment has not been fully studied ${ }^{[58]}$. For example, some studies have highlighted the significant impact of CSR on job acceptance ${ }^{[59]}$, while other studies suggest that CSR influences job intention, but not job acceptance and/or career expectations ${ }^{[60]}$. This suggests that, unlike the generally accepted view, future employees will pay more attention to pragmatism rather than altruism in job search behavior. Corporate social responsibility is considered to be a major factor in the career choice of potential employees $^{[61]}$. In addition, although existing studies have enriched people's understanding of the relationship between CSR and job seekers, and connected corporate social responsibility with recruitment activities in human resource management, the discussion on the influence mechanism and boundary conditions of corporate social responsibility on job seekers' attractiveness is not sufficient ${ }^{[53]}$. Especially in the context of China, there are few studies on the psychological reactions and actual choices of job seekers to enterprises' social responsibility activities in the labor market. Research on employee recruitment also shows that an organization's CSR affects its attractiveness as an employer, but the underlying mechanisms and processes of its occurrence remain unclear ${ }^{[53]}$. Given the strong recognition in the practice literature of the value of CSR as an effective recruitment tool, this seems to be an area of urgent need for further investigation. Therefore, future studies can further explore the mechanism of the relationship between CSR and organizational attractiveness.

Secondly, for internal corporate social responsibility, it is one of the future research directions to build a long-term guidance system for enterprises to actively fulfill employees' social responsibility. Have staffs on corporate social responsibility of the motivation of the research on corporate social responsibility and employee organization behavior and satisfaction are involved, however to clarify the driver under the action of employee social responsibility strategic management process and reaction dimensions, further study of the dimension driving factors of enterprise employee behavior and performance of internal mechanism of social responsibility, Therefore, one of the future research directions is to build a guiding mechanism of employee social responsibility based on the motivation of enterprises to undertake social responsibility, the effect of enterprises' performance of employee social responsibility behavior and the integration of corporate strategy, and solve the problem of lack of longterm mechanism and emergency system in enterprises' performance of employee social responsibility.

Finally, future research needs to pay more attention to the concretization of CSR research. When enterprises are in different environments, they bear different social responsibilities and have different impacts on the society. Therefore, further research is required depending on the type of enterprise. The research on corporate social responsibility in the early stage did not distinguish the research situation, but now began to pay attention to the differences of corporate social responsibility research in different situations, which will be an important development direction of corporate social responsibility research in the future. In addition, community is also one of the important stakeholders of enterprises. Some enterprises unilaterally pursue economic benefits, seriously pollute the local community environment and affect residents' lives. However, relevant researches in China are still worth further exploration. 


\section{References}

[1] Shuai Zhong, Qiyu Zhang, Gaojie LI, et al. Research on the effect of corporate social responsibility behavior on brand emotion from the perspective of emotion localization. Nankai Management Review, 2021(2):1-21.

[2] Madsen P M, Rodgers Z J. Looking good by doing good: The antecedents and consequences of stakeholder attention to corporate disaster relief[J]. Strategic Management Journal, 2015, 4 (5) : 776-794.

[3] Dacin B P A. The company and the product: corporate associations and consumer responses[J]. Journal of Marketing, 1997, 61(1):68-84.

[4] Aguinis H. Organizational responsibility: Doing good and doing well[J]. 2011.

[5] McWilliams, Abagail, Siegel, et al. Corporate social responsibility: a theory of the firm perspective.[J]. Academy of Management Review, 2001.

[6] Mackey A, Mackey T B, Barney J B. Corporate social responsibility and firm performance: Investor preferences and corporate strategies[J]. The Academy of Management Review, 2005, 32(3).

[7] Lei W, Juslin H. The impact of chinese culture on corporate social responsibility: Journal of Business Ethics, 2009, 88(suppl.3):433-451.

[8] Akremi A E, Gond J P, Swaen V, et al. How do employees perceive corporate responsibility? Development and validation of a multidimensional corporate stakeholder responsibility scale[J]. Journal of Management, 2018, 44 (2) : 619-657.

[9] Qian Luo. Research on the relationship between corporate social responsibility fulfillment and employer attraction in China [D]. Southwest Jiaotong University, 2011.

[10] Wenhong Sun, Kailin Chen. The construction of corporate social responsibility system from the perspective of public governance [J]. China Party and Government Cadres Forum, 2016(02): 85-87.

[11] Maignan I, Ferrell O C. Corporate citizenship as a marketing instrument concepts, evidence and research directions.[J]. European Journal of Marketing, 2001.

[12] Turker D. Measuring corporate social responsibility: Journal of Business Ethics, 2009, 85(4):411-427.

[13] Xianfu He, Yun Pu, Yuxia Zhu, et al. Revision and reliability and validity test of corporate social responsibility scale in Chinese context [J]. Soft science, 2010, 24(12):106-110.

[14] Hong Tian, Yufeng Jiang. Journal of social sciences of jilin university, 2014, 54(01): 150-158.

[15] Dahlsrud A. How corporate social responsibility is defined: Journal of The Chemical Society of The People's Republic of China, 2010, 36 (1):1-13.

[16] Sarkar S, Searcy C. Zeitgeist or chameleon? A quantitative analysis of CSR definitions[J]. Journal of Cleaner Production, 2016, 135(Nov. 1):1423-1435.

[17] Bing Hu, Ting Li, WenTong. Structural dimensions and model construction of social responsibility of listed Tourism Companies: an exploratory research based on grounded Theory[J]. Tourism Tribune, 2018, 33(10):31-40.

[18] Shangkun Xu, Rudai Yang. An inductive analysis of corporate social responsibility [J]. China Industrial Economics, 2007, 000(005):71-79.

[19] Liyin Jin. An empirical study on evaluation Index System of corporate social responsibility Movement - Consumer perspective [J]. China Industrial Economics, 2006(6):114-120.

[20] Hui Tang, Wang Zhou. Research on hotel social responsibility Evaluation System based on consumer Perspective [J]. Economic Research Guide, 2019000 (030) : 149-152, 168.

[21] Xiaojun Xu. Research on the Dimension of corporate social responsibility based on stakeholder Theory - From the Perspective of Consumer Cognition [D]. Tianjin University, 2020.

[22] Spence M. Signaling in Retrospect and the Informational Structure of Markets[J]. American Economic Review, 2002.95 (3) : 434-459.

[23] Michael S. Job Market Signaling[J]. Quarterly Journal of Economics, 1973(3):355-374.

[24] Bhattacharya C, Korschun D, Sen S. Strengthening Stakeholder-Company Relationships Through Mutually Beneficial Corporate Social Responsibility Initiatives[J]. Journal of Business Ethics, 2009, 85(2):257-272.

[25] Tajfel h. Social Relations: a Review [J]. Journal of Psychology, 2003, 33(1): 1-39. 
[26] Hogg M A, Reid S A. Social identity, self-categorization, Communication Theory, 2010, 16(1) : 1-6.

[27] Ashforth B E, Mael F. Social Identity Theory and the Organization[J]. Academy of Management Review, 1989, 14 (1): 20 to 39.

[28] Yingrui Zhang, Bin Zuo. Social identity theory and its development [J]. Advances in psychological science, 2006, 14(03):475-480.

[29] Jiannan Li. The Impact of corporate social Responsibility on Stakeholders [D]. Nanjing University, 2017.

[30] Peng Xie, LIU Chunlin. Moral legitimacy, regional isomorphism and corporate charitable giving behavior: A Case study of Listed Companies in China [J]. Nanjing Social Sciences, 2015(03):50-58.]

[31] Wei Huang, Zhao Chen. Foreign investment, supply chain pressure and Corporate social responsibility in China [J]. Management World, 2015(02):91-100.

[32] Hong Tian, Chunyuan Jiang. Research on the influence of socially responsible human resource Management on employees' pro-environment Behavior in tourism Enterprises [J]. Tourism Journal, 2021, 14 (3) : 1-16.

[33] Weber M. The business case for corporate social responsibility: Corporate governance and corporate governance: A case study in China [J]. Journal of Management science, 2008, 26(4):247-261.

[34] Carroll, Archie B. Carroll's pyramid of CSR: International Journal of Corporate Social Responsibility, 2016, 1(1):3.

[35] Brammer S J, Pavelin S. Corporate Reputation and Social Performance: The Importance of Fit[J]. Journal of Management Studies, 2010, 43(3):435-455.[37] Orlitzky M, Schmidt F L, Rynes S L. Corporate Social and Financial Performance: A Meta-Analysis[J]. Palgrave Macmillan UK, 2008.

[36] Wang H, Qian C. Corporate Philanthropy and Financial Performance: The Roles of Social Expectations and Political Access[J]. Zahedan Journal Of Research In Medical Sciences, 2011.

[37] Ana T V, Dubravka S. The relationship between reputation, Employer branding and corporate social responsibility[J]. Public Relations Review, 2018, 44:S1618526577.

[38] Swaen V, Demoulin N, Pauwels-Delassus V, et al. Impact of customers' perceptions regarding corporate social responsibility and irresponsibility in the grocery retailing industry: The role of corporate reputation[J]. Journal of Business Research, 2021(4):1-30.

[39] Mueller K, Hattrup K, Spiess S O, et al. The effects of corporate social responsibility on employees' affective commitment: Journal of Psychol Psychol, 2012, 97(6):1186-1200.

[40] Choi Y, Yu Y. The Influence of Perceived Corporate Sustainability Practices on Employees and Organizational Performance[J]. Sustainability, 2014, 6 (1) : 348-364.

[41] Aguinis H, Glavas A. What We Know and Don't Know About Corporate Social Responsibility A Review and Research Agenda[J]. Journal of Management, 2012, 38 (4) : 932-968.

[42] Weng Q X, Wu S. A meta-analysis of the influencing factors of organizational attractiveness: A Review based on the Research of the Past 25 years [J]. Forecast, 2015 (01) : 29-34.

[43] Turban D B, Greening D W. Corporate Social Performance and Organizational Attractiveness to Prospective Employees[J]. Proceedings of the International Association for Business \& Society, 2016.

[44] Aiman-Smith B L. Green career choices: Journal of Business \& Psychology, 1996, 10(4):445-458. (in Chinese)

[45] Behrend T S, Thompson B. Effects of Pro-Environmental Recruiting Messages: The Role of Organizational Reputation[J]. Journal of Business and Psychology, 2009, 24(3):341-350.

[46] Duarte A P, Gomes D R, Neves J. Finding the jigsaw piece for our jigsaw puzzle with corporate social responsibility: The Impact of CSR on prospective applicants' Responses [J]. Management Research, 2014(12):240-258.

[47] Min Tian, Chunqing Li, Qinglong Xiao. The impact of corporate social responsibility behavior on consumer brand evaluation [J]. Nankai management review, 2014, 17(06):19-29.

[48] Yuhua Xie, Jingjing Liu, Huaqing Xie. The impact of internal and external corporate social responsibility on employees' sense of work significance [J]. Chinese journal of management, 2020, 17(09):1336-1346.

[49] Penghui Tong, Dezhi Zhao. Research on the relationship between corporate social responsibility and employees' internal motivation [J]. Technology Economics and Management Research, 2018(11):60-64. 
[50] Weihua Ding, Yingshuang Bao, Tingting Wang. Research on the impact of corporate social responsibility on employee behavior [J]. Modern Business, 2021(16):73-75.

[51] Aimin Yan, Yuxia Wang, Liang Shan. The impact of corporate social responsibility on voice behavior in The Context of Chinese culture -- Based on the Moderating role of Confucian and Taoist work values [J]. Soft science, 2018, 32(07):48-51.

[52] Jones D A, Willness C R, Madey S. Why Are Job Seekers Attracted by Corporate Social Performance? Experimental and Field research of Three signal-based Mechanisms[J]. Academy of Management Journal, 2014, 57(2):383-404.

[53] Pfister M. Corporate Social Responsibility and Organizational Attraction: a Systematic Literature Review: 2020 Western Academy of Management (WAM) Conference, 2020[C].

[54] Greening, D. W, Turban, et al. Corporate Social Performance as a Competitive Advantage in Attracting a Quality Workforce[J]. Business And Society, 2000.

[55] Luce, Rebecca A, Barber, et al. Good Deeds and Misdeeds: A Mediated Model of the Effectof Corporate Social Performance on Organizational Attractiveness.[J]. Business \& Society, 2001.

[56] Lin Zhang, Xiayang Wang,Honghui Chen, et al. Is corporate social responsibility attractive to job seekers: An Empirical Study [J]. Nankai management review, 2017, 20(05):116-130.

[57] Podgorodnichenko N, Edgar F, Akmal A. An integrative literature review of the CSR-HRM nexus: Learning from research-practice gaps[J]. Human Resource Management Review, 2021(5).

[58] Kim S Y, Park H. Corporate Social Responsibility as an Organizational Attractiveness for Prospective Public Relations Practitioners[J]. Journal of Business Ethics, 2011, 103.

[59] Tsai Y H, Lin C P, Hsu Y C, et al. Predicting job offer acceptance of professionals in Taiwan: Technological Forecasting and Social Change, 2016, 108(Jul.):95-101.]

[60] Lis B. The Relevance of Corporate Social Responsibility for a Sustainable Human Resource Management: An Analysis of Organizational Attractiveness as a Determinant in Employees' Selection of a (Potential) Employer[J]. Management Revue, 2012, 23 (3) : 279-295. 